\title{
Macronutrients and caloric intake in health and longevity
}

\author{
Samantha M Solon-Biet ${ }^{1,2,3}$, Sarah J Mitchell ${ }^{4}$, Rafael de Cabo ${ }^{4}$, \\ David Raubenheimer ${ }^{1,3,5}$, David G Le Couteur ${ }^{1,2}$ and Stephen J Simpson ${ }^{1,3}$ \\ ${ }^{1}$ Charles Perkins Centre, Building D17, University of Sydney, Sydney, New South Wales 2006, Australia \\ ${ }^{2}$ ANZAC Research Institute and the Ageing and Alzheimers Institute, Centre for Education and Research on Ageing, \\ Concord Hospital, University of Sydney, Sydney, New South Wales, Australia \\ ${ }^{3}$ School of Biological Sciences, University of Sydney, Sydney, New South Wales, Australia \\ ${ }^{4}$ Translational Gerontology Branch, National Institute on Aging, National Institutes of Health, Baltimore, \\ Maryland 21224, USA \\ ${ }^{5}$ Faculty of Veterinary Science, University of Sydney, Sydney, New South Wales, Australia
}

Correspondence should be addressed to S M Solon-Biet Email samantha.solon-biet@ sydney.edu.au

\begin{abstract}
Both lifespan and healthspan are influenced by nutrition, with nutritional interventions proving to be robust across a wide range of species. However, the relationship between nutrition, health and aging is still not fully understood. Caloric restriction is the most studied dietary intervention known to extend life in many organisms, but recently the balance of macronutrients has been shown to play a critical role. In this review, we discuss the current understanding regarding the impact of calories and macronutrient balance in mammalian health and longevity, and highlight the key nutrient-sensing pathways that mediate the effects of nutrition on health and ageing.
\end{abstract}

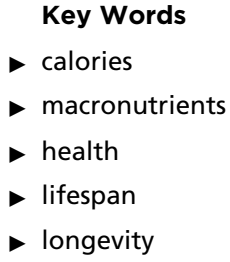

Journal of Endocrinology (2015) 226, R17-R28

\section{Introduction}

Aging is one of the greatest societal challenges in the modern world. Lifestyle choices, improved technology and modern medicine have contributed to a rapidly growing aging population (Partridge 2014). While we live longer on average than our ancestors, increased lifespan is not without its drawbacks. The primary problem with living longer is that with increasing age comes a heightened risk of chronic diseases such as cancer, type 2 diabetes, stroke, dementia and cardiovascular disorders, leading to disability and related mortality (Fontana et al. 2010, Piper et al. 2011, de Cabo \& Le Couteur 2015). Currently, the major focus of modern medicine is treating specific age-related diseases. However, with a growing number of older people encumbered with multiple chronic conditions (Fontana et al. 2014), this approach is problematic, e.g. leading to complications arising from multiple medications for different conditions (de Cabo \& Le Couteur 2015). Rather than treat the symptoms of aging, a logical alternative approach would be to intervene in the aging process itself (Partridge 2014).

Interventions that slow the rate of aging and increase healthspan and lifespan have been of considerable interest over the past 80 years. While genetic and pharmaceutical interventions have been widely explored in laboratory models (Kenyon et al. 1993, Baur et al. 2006, Mitchell et al . 2014), translating such approaches to humans is difficult (Fontana \& Partridge 2015). Nutritional manipulations, however, have proven to be similarly robust across multiple animal models and humans, with profound impacts on reproduction, health and aging. However, the complex relationship between nutrition and agerelated health is not fully understood. A growing body of evidence has pointed to dietary restriction as an important mediator of health and lifespan (Masoro 2000, 2003,

Published by Bioscientifica Ltd. 
Miller et al. 2005, Piper et al. 2011). But what does dietary restriction actually mean? Throughout the literature, dietary restriction is often used interchangeably with caloric restriction (CR). Whereas dietary restriction can involve different feeding regimens such as intermittent fasting or alternate day feeding (Ingram \& Roth 2015), CR refers more specifically to the reduction of total calorie intake by $20-50 \%$ without malnutrition (Weindruch et al. 1986, Masoro 2005). Recent evidence suggests that the balance of macronutrients, rather than total energy intake, plays a larger role in lifespan extension than previously attributed (Zimmerman et al. 2003, Mair et al. 2005, Solon-Biet et al. 2014). Whether calories or specific nutrients affect aging is a critically important issue to resolve, with important implications for aging research (Simpson \& Raubenheimer 2007). In this review, we discuss the current understanding and impact of both calories and macronutrients on health and lifespan based on studies in invertebrate and mammalian models, and highlight the use of nutritional geometry as a framework to help disentangle the complex relationship between diet and healthy aging.

\section{Dietary restriction}

There is widespread consensus in aging research that eating fewer calories results in a longer, healthier life. To date, CR has been the primary focus of most non-genetic nutritional interventions (Mattison et al. 2003, Ingram et al. 2004, Sinclair 2005). Yeasts, nematode worms, fruit flies, rodents and even non-human primates have been used as models for the study of CR and aging, suggesting that these effects must act via evolutionarily conserved mechanisms (Fig. 1; Weindruch et al. 1986, Lin et al. 2000). Since the first account of the life-extending effects of CR in rats in the early 1930s, there has been a substantial amount of research into the dietary basis of aging (McCay et al. 1935). It was not until the early 1980s that the idea of $\mathrm{CR}$ as a viable model for aging and the study of age-related diseases really came to fruition (Masoro et al. 1982, Masoro 1991, Walford et al. 1992). Despite the great strides made towards understanding the mechanisms of CR, much still remains unknown. Initial work exploring $\mathrm{CR}$ as a robust nutritional intervention for aging began with yeasts, worms and flies. In yeast (Saccharomyces cerevisiae), CR is mediated by reduced glucose levels, extending both overall lifespan and replicative lifespan (Kaeberlein et al. 2005, Powers et al. 2006, Bonawitz et al. 2007) and in the worm Caenorhabditis elegans and the fruit fly Drosophila melanogaster, some forms of food restriction via nutrient

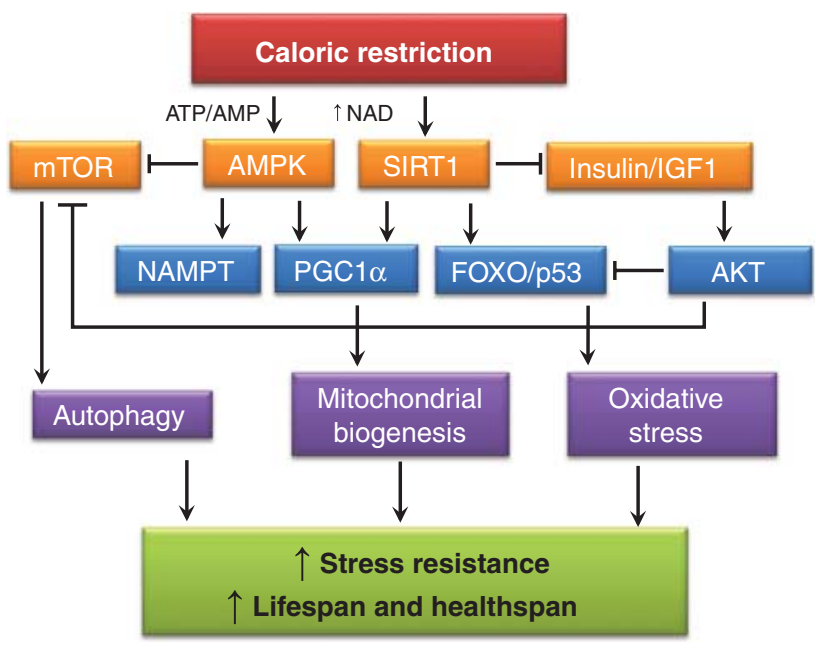

Figure 1

The complex metabolic network of potential players in the mechanism of caloric restriction (CR). A reduction in energy intake influences cellular energy levels, activating the AMPK and SIRT1 pathways. Antagonistic responses include the inhibition of the anabolic pathways $\mathrm{mTOR}$ and insulin/IGF1. Downstream effects result in increased stress resistance and improved lifespan and healthspan.

manipulation also successfully extended lifespan (Partridge et al. 2005, Taormina \& Mirisola 2014). Interestingly, the beneficial effect of CR does not appear to be universal. Although experiments in rodents produces a net beneficial effect to overall metabolic health in laboratory animals (Masoro 2000, Ingram et al. 2004, Bordone \& Guarente 2005), the effects on lifespan extension are highly dependent on various other factors such as strain and sex (Festing \& Blackmore 1971, Yuan et al. 2009, Liao et al. 2010). On average, 40\% CR extends maximal lifespan in male B6D2F1 mice by $20 \%$ relative to ad libitum fed controls (Wolf et al. 1995). However, whether this effect also extends to females remains to be seen. We do know that CR extends lifespan in genetically heterogeneous mice created from four inbred strains (BALB/c, C57BL/6, C3H and DBA2), although more than $90 \%$ died of cancer, which may not be representative of the human situation (Miller et al. 2011). Translation into longer-lived mammals has continued to show conflicting results (Liao et al. 2010, Mattison et al. 2012). Two longterm studies in non-human primates were initiated in the early 1980s in order to address this question. Although both studies confirm the findings that CR delays the onset of age-associated diseases, CR monkeys from the National Institute on Aging (NIA) did not live longer than their ad libitum fed counterparts, which is in contrast to results obtained in the Wisconsin cohort (Colman et al. 2009,

Published by Bioscientifica Ltd 
2014, Mattison et al. 2012). These results were attributed to possible discrepancies in diet design and diet composition (Mattison et al. 2012). NIA monkeys were fed a diet rich in natural ingredients such as protein derived primarily from plant sources while the Wisconsin monkeys were fed a semi-purified diet with protein derived from lactalbumin (Ingram et al. 1990, Ramsey et al. 2000). Carbohydrate quality also differed between studies with the NIA diets containing significantly less sucrose than the Wisconsin study (Mattison et al. 2012).

Such studies highlight the question of whether CR per se is solely responsible for extended longevity or if particular macronutrients or a balance of macronutrients is more important (Table 1). While the effect of CR on human lifespan is yet to be determined, CR has been shown to improve several markers of health (Heilbronn et al. 2006, Fontana et al. 2010). But despite these benefits, a central limitation is that compliance to lifetime CR is challenging in humans and the risk of missing essential nutrients can be detrimental to reproduction, bone structure and overall metabolic health (Fontana \& Partridge 2015, Ingram \& Roth 2015). Hence, dietary interventions involving ad libitum access to diets designed to prolong healthspan would be of greater utility than CR.

\section{CR or protein restriction?}

Recent studies have suggested that the beneficial effects of CR on lifespan may be due to the reduced intake of specific dietary components such as proteins, rather than total energy intake (Zimmerman et al. 2003, Mair et al. 2005, Piper et al. 2005, Pamplona \& Barja 2006) with these effects acting largely through the same evolutionarily conserved signaling pathways (Fig. 2). The restriction of protein intake, rather than energy, may offer a more feasible nutritional intervention in humans. Work by McCay as early as 1929 reported that a low protein diet extended the lifespan of trout (McCay et al. 1929). Since then, it has been shown that the restriction of essential amino acids can increase lifespan in honeybees (Paoli et al. 2014), and the restriction of particular amino acids, such as methionine, can extend lifespan in mice (Sun et al. 2009) and rats (Orentreich et al. 1993, Richie et al. 1994), and lower the levels of serum insulin-like growth factor 1 (IGF1), insulin, glucose and thyroid hormone in $(\mathrm{BALB} / \mathrm{cJ} \times$ C57BL/6J) F1 mice (Miller et al. 2005). Recently, the restriction of essential amino acids (Robertson et al. 2015) and the sulfur amino acids methionine and cysteine (Robertson et al. 2015) have been shown to protect against hepatic ischemia reperfusion injury by preconditioning against oxidative stress, complications of cardiovascular surgery (Robertson et al. 2015) and mediating hydrogen sulfide $\left(\mathrm{H}_{2} \mathrm{~S}\right)$ production (Hine et al. 2015). $\mathrm{H}_{2} \mathrm{~S}$ production under protein restriction exerts a hormetic response, acting on brain signaling and the vascular system to reduce blood pressure and trigger the same signaling response cascade observed in animals fed proteinrestricted diets via activation of GCN2, eIF2 $\alpha$ and ATF4 and repression of mechanistic target of rapamycin (mTOR; Fig. 2; Hine et al. 2015, Robertson et al. 2015). Moreover, a meta-analysis of animal studies of CR and aging conclude that the restriction of protein, rather than CR, appeared to have the greatest effect on delaying aging (Nakagawa et al. 2012). Data in humans indicate that reduced protein intake may become an important component of anticancer and anti-aging dietary interventions (Fontana et al. 2008, Levine et al. 2014).

\section{Macronutrient balance}

While both CR and protein restriction have been shown to impact aging, a fundamental limitation of these two onevariable-at-a-time approaches is that they cannot disentangle the interactive effects of nutrients and calories (Simpson et al. 2015). Recent studies have begun to tackle these interactions and show the importance of the balance of macronutrients on health and aging. Such evidence has been derived using the Geometric Framework (GF) for nutrition (Simpson \& Raubenheimer 2009, 2012). In the GF, nutrition is represented in an $n$-dimensional space, in which the components of $n$ represent focal dietary components (e.g. macronutrients). Various phenotypic responses (e.g. lifespan) can be modelled onto this $n$-dimensional space, providing a detailed landscape of the effects of nutrition. Using this framework allows the use of nutritional geometry to simultaneously interpret the effects of energy, individual macronutrients (or other focal dietary components) and the interactions within and between nutrients (Piper et al. 2011, Simpson \& Raubenheimer 2012). This framework has helped to resolve conflicting ideas about the nutritional determinants of health and aging, and to reconcile views on resource-mediated trade-offs between reproduction and longevity (Lee et al. 2008, Tatar et al. 2014, Jensen et al. 2015, Solon-Biet et al. 2015a).

Studies in both invertebrates and mice show that reproduction and longevity do not trade-off against one another, rather these responses have different nutritional requirements. In the field cricket Teleogryllus commodus and fruit fly D. melanogaster, the macronutrient blend that

Published by Bioscientifica Ltd 

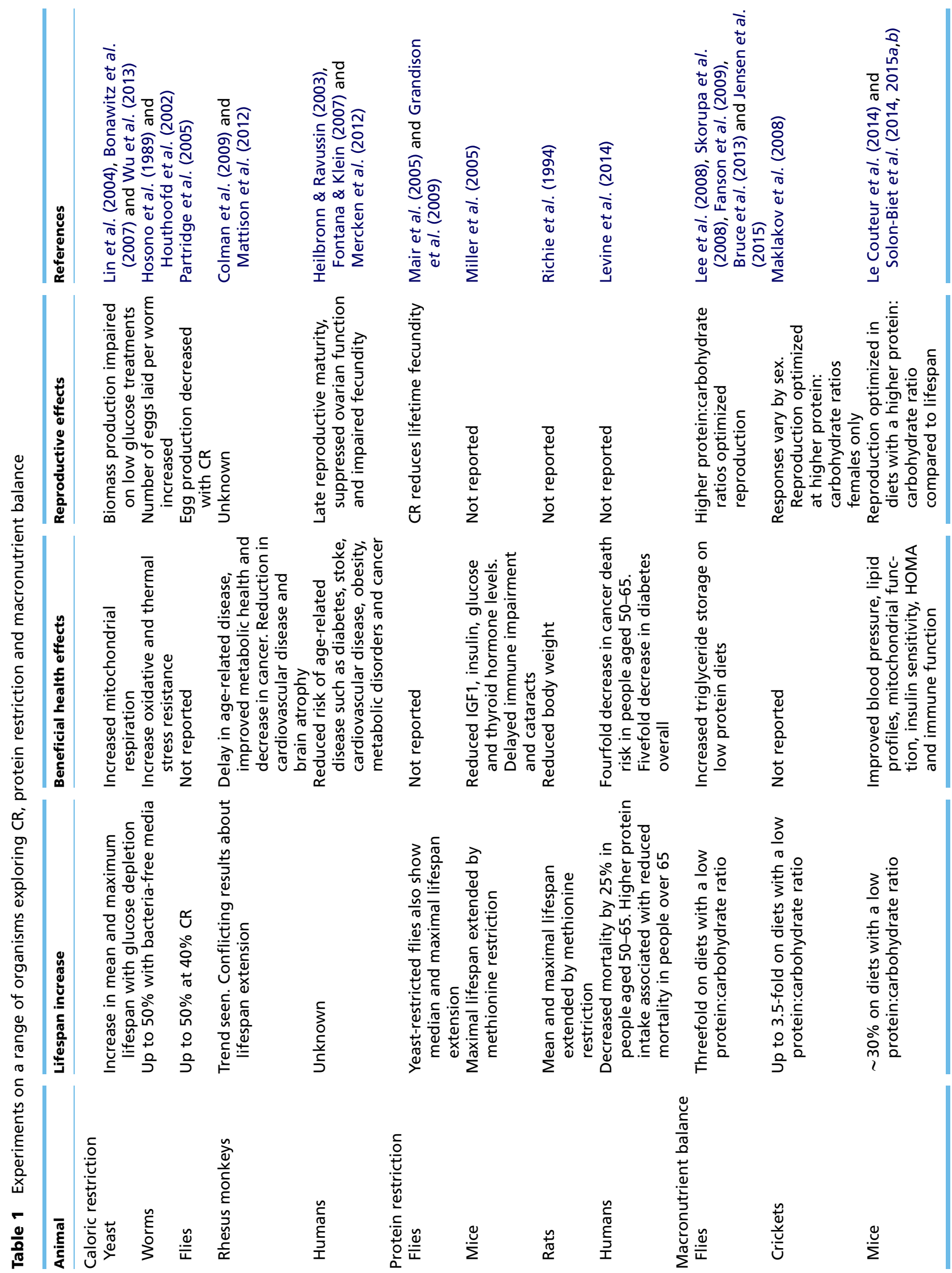


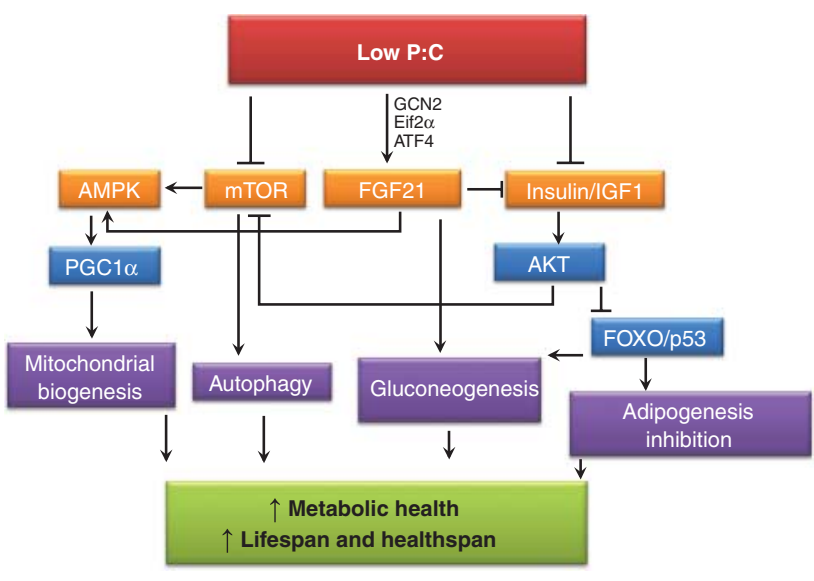

Figure 2

The complex metabolic network of potential players in the mechanism of low protein:carbohydrate $(P: C)$ diets. Low $P: C$ diets activate GCN2 and FGF21 and inhibit activation of mTOR and insulin/IGF1. Inhibition of these pathways activate AMPK and AKT, resulting in improved metabolic health, lifespan and healthspan.

maximized lifespan was markedly different from diets which maximized reproductive variables (Maklakov et al. 2008, Jensen et al. 2015). Maximal longevity occurred on low protein (P), high carbohydrate (C) diets in both males and females, while a higher P:C ratio was better for reproduction in females only. Consuming a low proportion of protein in the diet relative to carbohydrate, not total calories, extended lifespan in ad libitum-fed flies (Lee et al. 2008, Bruce et al. 2013), while diets with a higher proportion of protein shortened lifespan but improved reproduction (Lee et al. 2008). This result has been replicated in several other insect species (Lee et al. 2008, Dussutour \& Simpson 2009, Fanson et al. 2009, Grandison et al. 2009, Piper et al. 2011) and consistently indicates that the balance of macronutrients is the chief nutritional cue that directs metabolism towards longevity or reproduction (Wilder et al. 2012). A recent study in mice showed that ad libitum low protein, high carbohydrate diets fed short-term improved several markers of health including insulin, homeostatic model assessment (HOMA), glucose tolerance and triglycerides to a level comparable to CR, but without at $40 \%$ reduction in total calorie intake (Solon-Biet et al. 2015b). Long-term investigations in ad libitum-fed mice across 25 different diets varying in macronutrient composition support these findings, showing that latelife health and longevity were optimized not by reducing energy intake, but by low P:C diets (Solon-Biet et al. 2014). In an attempt to stabilize protein intake, mice displayed a compensatory increase in food intake on low protein diets, resulting in increased energy intake and greater adiposity, but experienced a significant increase in lifespan, improved blood pressure, lipid profiles, mitochondrial function, insulin sensitivity (Solon-Biet et al. 2014) and immune function ( $\mathrm{T}$ and $\mathrm{B}$ cell populations) measured at 15 months (Le Couteur et al. 2014). These health and longevity consequences were shown to be related to circulating branched chain amino acid (BCAA) levels, which, interestingly, were the only amino acids to be positively correlated to protein intake under chronic feeding conditions. BCAA levels were the lowest in mice on the low protein, high carbohydrate diets correlating to diet treatments that yielded the longest health and lifespan.

Reports about the role of BCAAs in aging and health are seemingly divergent. Some suggest that elevated BCCAs are harmful because they are linked with obesity and diabetes, while others suggest that BCAAs should be supplemented to increase mitochondrial biogenesis (D'Antona et al. 2010). For example, in a major review, Newgard (2012) noted that human epidemiological studies and animal studies show that elevated BCAAs are associated with and predict diabetes, obesity and heart disease, while animal and cell studies show that BCAA supplementation increases activation of certain nutrient signaling pathways which are detrimental for aging (Chotechuang et al. 2009). In another review, Valerio et al. (2011) argue that BCAAs increase mitochondrial biogenesis and muscle function, thus BCAA supplementation should be considered as a treatment for older people. While the exact roles of BCAAs in health and lifespan are yet to be determined, evidence suggests that BCAAs may be an important mediator of key molecular pathways that link nutrition with aging.

\section{Nutrient-sensing pathways}

Nutrient-sensing pathways that mediate the effects of nutrition on health and aging have been explored in many experimental models (Fontana et al. 2010, Hubbard \& Sinclair 2014, Chantranupong et al. 2015). These include the evolutionarily conserved key regulators mTOR, AMPactivated protein kinase (AMPK), insulin/IGF1 and sirtuins. Both calories and macronutrients influence these pathways which have evolved to respond to periods of famine by switching cells and organism from their focus on growth and reproduction, towards survival and resilience (Fig. 3; Kapahi et al. 2010, Speakman \& Mitchell 2011, Le Couteur et al. 2012). Although there are at least four key nutrient-sensing pathways implicated in longevity, these interact and share many downstream targets

Published by Bioscientifica Ltd. 


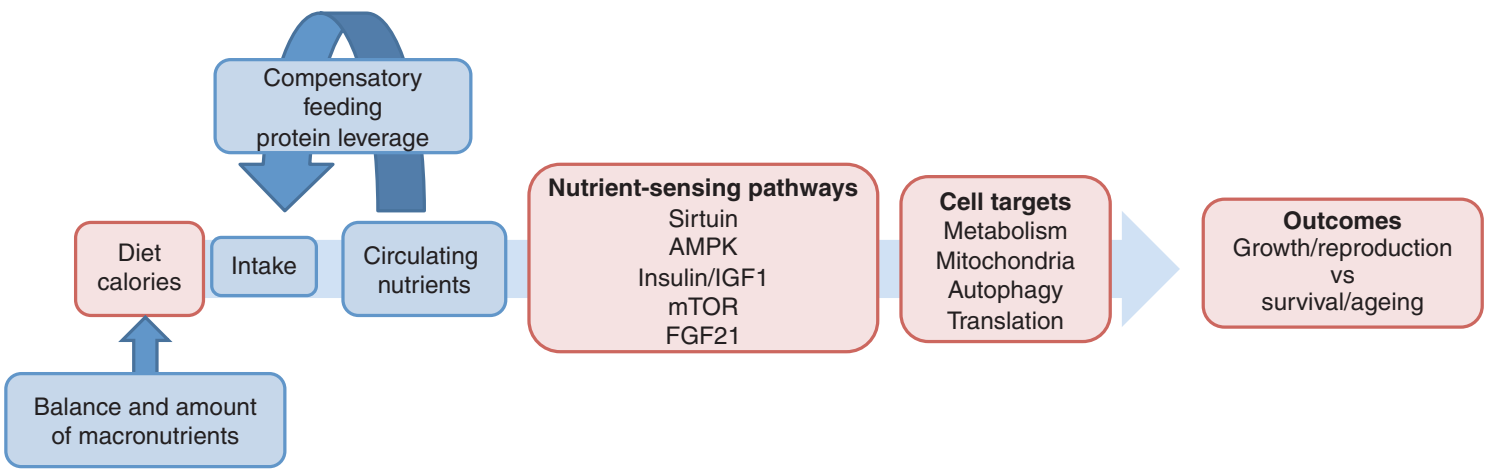

Figure 3

Schema showing the mechanism for the beneficial effects of caloric restriction on aging. The red boxes show the standard view based on energy intake. The impact of the balance of macronutrients and compensatory feeding in ad libitum diets in relation to this pathway (blue boxes). This more closely approaches real-life feeding in animals and humans that have unlimited access to food across a wide range of macronutrient compositions. that regulate cell processes involved in aging, including mitochondrial biogenesis, cellular metabolism, autophagy, DNA repair and expression, and translation.

\section{Mechanistic target of rapamycin}

In eukaryotic cells, mTOR is highly conserved and acts as a central regulator of growth and metabolism in response to nutrient and growth factor cues (Stanfel et al. 2009). This pathway is involved in anabolic processes including protein and lipid synthesis (Efeyan et al. 2015). mTOR integrates input from various pathways, including insulin and IGF1, and responds to dietary protein, particularly BCAAs (Chotechuang et al. 2009, Solon-Biet et al. 2014). In addition, mTOR responds to changes in cellular energy levels, altered genetic makeup, gene manipulations and pharmacological interventions that affect lifespan (Arsham et al. 2003, Wang \& Proud 2009, Tato et al. 2011). In mammals, mTOR has two structurally and functionally distinct multiprotein complexes: mTORC1 and mTORC2 which are differentiated by their accessory proteins, Raptor and Rictor (Jacinto et al. 2004). mTORC1 is the only complex sensitive to amino acids (Yuan et al. 2013) and is the primary modulator of protein, lipid, nucleotide synthesis and autophagy while mTORC2 is involved in cell proliferation and survival (Chantranupong et al. 2015). In animal models, it has been demonstrated that inhibition of mTOR protects against metabolic dysfunction, obesity, cancer and neurodegeneration (Stanfel et al. 2009) which can be achieved through pharmaceutical interventions such as rapamycin (Harrison et al. 2009, Miller et al. 2011) or nutritional interventions such as alterations in the ratio of dietary P:C (Solon-Biet et al. 2014). In mice, mTOR was activated most strongly by the ratio of circulating BCAA to glucose (i.e. the P:C), providing a key mechanistic link from the longevity and health impacts of low P:C diets to the mTOR pathway. Reducing mTOR signaling is critical for improved health and lifespan.

\section{AMP-activated protein kinase}

AMPK regulates cellular uptake of glucose, $\beta$-oxidation of fatty acids, the glucose transporter 4 (GLUT4) and mitochondrial biogenesis. Activation of AMPK has been proposed as one of the mechanisms through which CR has beneficial effects on lifespan and healthspan (Cantó \& Auwerx 2011). AMPK is a serine/threonine protein kinase, which is activated by cellular stresses that alter the AMP:ATP ratio resulting in depletion of ATP. As a consequence, ATP-consuming pathways are turned off, while ATP generation is turned on (Dagon et al. 2006). AMPK is a heterotrimeric protein comprised of one catalytic $(\alpha)$ and two regulatory ( $\beta$ and $\gamma$ ) subunits containing the kinase domain which when phosphorylated results in increased AMPK activity (Dagon et al. 2006). Recently, Mair et al. (2011) showed that CREB protein-regulated transcriptional co-activator (CRTC1) is an essential target for AMPK-mediated lifespan extension in C. elegans. Longevity via transcriptional regulation of AMPK occurred through CRTC1 downregulation, with neuronal CRTC1 playing a primary role in regulating

Published by Bioscientifica Ltd 
longevity and mitochondrial metabolism in peripheral tissues (Mair et al. 2011, Burkewitz et al. 2015). In mammals, hepatic AMPK activation acts to slow gluconeogenesis and downregulate key genes such as G6Pase and PEPCK, while in the muscle, it stimulates glucose uptake by increasing expression of glucose transporters such as GLUT4 (McCarty 2004). The cardioprotective effects of short-term CR are thought to be mediated through AMPK activation (Shinmura et al. 2007). Administration of the drug metformin enhances lifespan in mice and this is accompanied by an increase in AMPK activity (Martin-Montalvo et al. 2013), hence AMPK modulation represents an attractive target for inducing CR-like benefits. By activating this nutrient sensor, AMPK can extend healthspan and lifespan by restoring energy balance via catabolic responses such as fatty acid oxidation, proteolysis and inhibiting processes not essential for survival such as cell growth and proliferation (Cantó et al. 2009). These responses have been shown to underlie the beneficial effects of CR. Whether AMPK activation reflects the balance of dietary macronutrients as well as measures of energy status remains to be seen, but has been postulated (Simpson \& Raubenheimer 2009).

\section{Sirtuin pathway: SIRT1}

Sirtuins have been shown to regulate the aging process and mediate CR-induced longevity in organisms including S. cerevisiae, C. elegans and D. melanogaster (Guarente \& Kenyon 2000). Sirtuins are class III histone deacetylases that require $\mathrm{NAD}^{+}$as a cosubstrate. $\mathrm{CR}$ increases cellular $\mathrm{NAD}^{+}$as a consequence of reduced energy intake, thereby activating sirtuins. In mammals, there are seven homologs (SIRT1-7) that have been identified. SIRT1 remains perhaps the best and most studied, which is likely due to it sharing the most sequence similarity with the yeast Sir2 (Frye 2000, Allard et al. 2009). SIRT1 has multiple functions, some of which are outlined in Fig. 1, and include deacetylation of a large number of transcription factors (Guarente 2006, Longo \& Kennedy 2006, Boily et al. 2008), and regulation of PGC1 $\alpha$ (Rodgers et al. 2005, Gerhart-Hines et al. 2007, Sun et al. 2007). In middle-aged rats, CR has been reported to increase the expression of SIRT1 protein in brain, fat, kidney and liver (Cohen et al. 2004, Nisoli et al. 2005). In young CR mice, SIRT1 protein expression was increased in muscle and fat but markedly reduced in the liver (Chen et al. 2008). The SIRT1 protein, but not its increased expression, is essential for lifespan extension in CR mice (Mercken et al. 2013). There is a number of pharmacological agents that allosterically activate SIRT1 and delay aging, including resveratrol and SRT2014 (Howitz et al. 2003, Baur et al. 2006, Milne et al. 2007, Mercken et al. 2014, Sinclair \& Guarente 2014). Notably, resveratrol increased lifespan in mice fed a high fat diet but not in mice on standard chow where only health benefits were observed (Baur et al. 2006, Pearson et al. 2008). This suggests that activation of the SIRT1 pathway may have its greatest effect on aging where there is high energy intake and greatest inhibition of SIRT activity.

\section{Insulin/IGF1}

Lower levels of insulin and IGF1 induced by CR or low P:C diets are associated with improved health and increased lifespan across taxa including humans (Fontana et al. 2010, Miller et al. 2011, Levine et al. 2014). Mice with mutations along the growth hormone-IGF1-insulin pathway have been shown to be long-lived (Flurkey et al. 2001, Hsieh et al. 2002) and low IGF1 levels in humans can predict survival in people with exceptional longevity (Milman et al. 2014). The balance of macronutrients, namely low P:C, reduces insulin levels and HOMA in mice (Solon-Biet et al. 2014) supporting findings that inhibiting this pathway through diet is important for healthspan and lifespan extension. Moderating insulin secretion either by diet or administration of metformin can reduce insulin/ IGF1 signaling via activation of AMPK (McCarty 2004), facilitating glucose uptake into the cell, reducing glucose, insulin and IGF1 levels, leading to the prevention, or even reversal, of insulin resistance (Minor et al. 2010).

\section{Fibroblast growth factor 21: an emerging key regulator?}

A recent potential addition to these four classical nutrient sensing pathways is fibroblast growth factor 21 (FGF21), which is emerging as an endocrine signal associated with metabolic control. It is increased in response to acute starvation but also in the obese/diabetic condition, with a recent study showing that low protein intake is the major stimulant for its expression in liver and subsequent increase in the circulation (Laeger et al. 2014). FGF21 regulates several metabolic functions (gluconeogenesis, mitochondrial activity, ketogenesis, lipid metabolism and energy expenditure), which would be expected to be beneficial for age-related health. Similar effects have been reported in response to dietary methionine restriction (Lees et al. 2014, Stone et al. 2014). Although circulating FGF21 derives primarily from liver, it is also expressed in other metabolically important tissues, including white

Published by Bioscientifica Ltd. 
and brown adipose tissue, skeletal muscle, heart and pancreas (exocrine and $\beta$ cells). Such a pattern of expression is indicative of a role for this hormone in metabolic control. Just as for the four other nutrient sensing pathways previously discussed are highly interconnected, FGF21 too, plays a communicated role in nutrient signaling and has been shown to activate AMPK and SIRT1 (Chau et al. 2010), suggesting a role for FGF21 in linking nutrition and aging.

\section{Outlook}

This review has focused primarily on the relationships between calories and macronutrients and their effects on health and aging. Although both CR and macronutrient balance have profound impacts on health and lifespan, it is important to note that other dietary regimens such as intermittent fasting and time-restricted feeding, also have beneficial effects in both mice and humans (Mattson et al. 2014, Fontana \& Partridge 2015). The fact that results of Solon-Biet et al. (2014) show that limiting energy intake by dilution under ad libitum conditions has no benefit, yet under CR protocols it does, must suggest that it is not just the restriction per se that matters, but also the timing of intake (Simpson et al. 2015). Exactly how the complex network of nutrient signaling pathways interact to mediate the effects of various feeding regimens remains to be investigated. Although considerable research has gone into understanding these underlying mechanisms, none have yet studied it as a function of multiple nutrient dimensions. As highlighted in a recent review (Simpson et al. 2015), different nutritional interventions will have different effects on these pathways and understanding exactly how multiple nutrient dimensions affect these pathways can only be done using a framework that integrates these components simultaneously. The GF is such a tool. Exactly how calories and macronutrients, and the interplay of both, influence these pathways is a fundamental question to resolve. A better understanding can have important implications for diet management, disease prevention and pharmaceutical interventions.

\section{Declaration of interest}

The authors declare that there is no conflict of interest that could be perceived as prejudicing the impartiality of this review.

\section{Funding}

This review did not receive any specific grant from any funding agency in the public, commercial or not-for-profit sector.

\section{Acknowledgements}

This review was, in part, supported by the Intramural Research Program of the National Institute on Aging, National Institutes of Health.

\section{References}

Allard JS, Perez E, Zou S \& de Cabo R 2009 Dietary activators of Sirt1. Molecular and Cellular Endocrinology 299 58-63. (doi:10.1016/j.mce. 2008.10.018)

Arsham AM, Howell JJ \& Simon MC 2003 A novel hypoxia-inducible factorindependent hypoxic response regulating mammalian target of rapamycin and its targets. Journal of Biological Chemistry $\mathbf{2 7 8}$ 29655-29660. (doi:10.1074/jbc.M212770200)

Baur JA, Pearson KJ, Price NL, Jamieson HA, Lerin C, Kalra A, Prabhu VV, Allard JS, Lopez-Lluch G, Lewis K et al. 2006 Resveratrol improves health and survival of mice on a high-calorie diet. Nature 444 337-342. (doi:10.1038/nature05354)

Boily G, Seifert EL, Bevilacqua L, He XH, Sabourin G, Estey C, Moffat C, Crawford S, Saliba S, Jardine K et al. 2008 SirT1 regulates energy metabolism and response to caloric restriction in mice. PLOS ONE 3 e1759. (doi:10.1371/journal.pone.0001759)

Bonawitz ND, Chatenay-Lapointe M, Pan Y \& Shadel GS 2007 Reduced TOR signaling extends chronological life span via increased respiration and upregulation of mitochondrial gene expression. Cell Metabolism 5 265-277. (doi:10.1016/j.cmet.2007.02.009)

Bordone L \& Guarente L 2005 Calorie restriction, SIRT1 and metabolism: understanding longevity. Nature Reviews Molecular Cell Biology 6 298-305. (doi:10.1038/nrm1616)

Bruce KD, Hoxha S, Carvalho GB, Yamada R, Wang H-D, Karayan P, He S, Brummel T, Kapahi P \& Ja WW 2013 High carbohydrate-low protein consumption maximizes Drosophila lifespan. Experimental Gerontology 48 1129-1135. (doi:10.1016/j.exger.2013.02.003)

Burkewitz K, Morantte I, Weir HJ, Yeo R, Zhang Y, Huynh FK, Ilkayeva OR, Hirschey MD, Grant AR \& Mair WB 2015 Neuronal CRTC-1 governs systemic mitochondrial metabolism and lifespan via a catecholamine signal. Cell 160 842-855. (doi:10.1016/j.cell.2015.02.004)

Cantó C \& Auwerx J 2011 Calorie restriction: is AMPK a key sensor and effector? Physiology 26 214-224. (doi:10.1152/physiol.00010.2011)

Cantó C, Gerhart-Hines Z, Feige JN, Lagouge M, Noriega L, Milne JC, Elliott PJ, Puigserver P \& Auwerx J 2009 AMPK regulates energy expenditure by modulating $\mathrm{NAD}^{+}$metabolism and SIRT1 activity. Nature 458 1056-1060. (doi:10.1038/nature07813)

Chantranupong L, Wolfson RL \& Sabatini DM 2015 Nutrient-sensing mechanisms across evolution. Cell 161 67-83. (doi:10.1016/j.cell.2015. 02.041)

Chau MD, Gao J, Yang Q, Wu Z \& Gromada J 2010 Fibroblast growth factor 21 regulates energy metabolism by activating the AMPKSIRT1-PGC-1 $\alpha$ pathway. PNAS 107 12553-12558. (doi:10.1073/pnas. 1006962107)

Chen D, Bruno J, Easlon E, Lin S-J, Cheng H-L, Alt FW \& Guarente L 2008 Tissue-specific regulation of SIRT1 by calorie restriction. Genes and Development 22 1753-1757. (doi:10.1101/gad.1650608)

Chotechuang N, Azzout-Marniche D, Bos C, Chaumontet C, Gausseres N, Steiler T, Gaudichon C \& Tome D 2009 mTOR, AMPK, and GCN2 coordinate the adaptation of hepatic energy metabolic pathways in response to protein intake in the rat. American Journal of Physiology. Endocrinology and Metabolism 297 E1313-E1323. (doi:10.1152/ajpendo. 91000.2008)

Cohen HY, Miller C, Bitterman KJ, Wall NR, Hekking B, Kessler B, Howitz KT, Gorospe M, de Cabo R \& Sinclair DA 2004 Calorie restriction promotes mammalian cell survival by inducing the SIRT1 deacetylase. Science 305 390-392. (doi:10.1126/science.1099196)

Colman RJ, Anderson RM, Johnson SC, Kastman EK, Kosmatka KJ, Beasley TM, Allison DB, Cruzen C, Simmons HA, Kemnitz JW et al.

Published by Bioscientifica Ltd. 
2009 Caloric restriction delays disease onset and mortality in rhesus monkeys. Science 325 201-204. (doi:10.1126/science.1173635)

Colman RJ, Beasley TM, Kemnitz JW, Johnson SC, Weindruch R \& Anderson RM 2014 Caloric restriction reduces age-related and all-cause mortality in rhesus monkeys. Nature Communications 53557. (doi:10.1038/ncomms4557)

Dagon Y, Avraham Y \& Berry EM 2006 AMPK activation regulates apoptosis, adipogenesis, and lipolysis by eIF $2 \alpha$ in adipocytes. Biochemical and Biophysical Research Communications 340 43-47. (doi:10.1016/j.bbrc.2005.11.159)

D’Antona G, Ragni M, Cardile A, Tedesco L, Dossena M, Bruttini F, Caliaro F, Corsetti G, Bottinelli R, Carruba MO et al. 2010 Branched-chain amino acid supplementation promotes survival and supports cardiac and skeletal muscle mitochondrial biogenesis in middle-aged mice. Cell Metabolism 12 362-372. (doi:10.1016/j.cmet.2010.08.016)

de Cabo R \& Le Couteur DG 2015 The biology of aging. In Harrison's Principles of Internal Medicine, 19th edn. Eds D Kasper, A Fauci, S Hauser, D Longo, J Jameson \& J Loscalzo. McGraw-Hill Education: Columbus, $\mathrm{OH}, \mathrm{USA}$.

Dussutour A \& Simpson SJ 2009 Communal nutrition in ants. Current Biology 19 740-744. (doi:10.1016/j.cub.2009.03.015)

Efeyan A, Comb WC \& Sabatini DM 2015 Nutrient-sensing mechanisms and pathways. Nature $\mathbf{5 1 7} 302-310$. (doi:10.1038/nature14190)

Fanson BG, Weldon CW, Pérez-Staples D, Simpson SJ \& Taylor PW 2009 Nutrients, not caloric restriction, extend lifespan in Queensland fruit flies (Bactrocera tryoni). Aging Cell 8 514-523. (doi:10.1111/j.1474-9726. 2009.00497.x)

Festing MF \& Blackmore DK 1971 Life span of specified-pathogen-free (MRC category 4) mice and rats. Laboratory Animals 5 179-192. (doi:10.1258/002367771781006564)

Flurkey K, Papaconstantinou J, Miller RA \& Harrison DE 2001 Lifespan extension and delayed immune and collagen aging in mutant mice with defects in growth hormone production. PNAS 98 6736-6741. (doi:10.1073/pnas.111158898)

Fontana L \& Klein S 2007 Aging, adiposity, and calorie restriction. JAMA 297 986-994. (doi:10.1001/jama.297.9.986)

Fontana L \& Partridge L 2015 Promoting health and longevity through diet: from model organisms to humans. Cell 161 106-118. (doi:10.1016/j.cell.2015.02.020)

Fontana L, Weiss EP, Villareal DT, Klein S \& Holloszy JO 2008 Long-term effects of calorie or protein restriction on serum IGF-1 and IGFBP-3 concentration in humans. Aging Cell 7 681-687. (doi:10.1111/j.14749726.2008.00417.x)

Fontana L, Partridge L \& Longo VD 2010 Extending healthy life span from yeast to humans. Science 328 321-326. (doi:10.1126/science. 1172539)

Fontana L, Kennedy BK, Longo VD, Seals D \& Melov S 2014 Medical research: treat ageing. Nature $\mathbf{5 1 1} 405-407$. (doi:10.1038/511405a)

Frye RA 2000 Phylogenetic classification of prokaryotic and eukaryotic Sir2-like proteins. Biochemical and Biophysical Research Communications 273 793-798. (doi:10.1006/bbrc.2000.3000)

Gerhart-Hines Z, Rodgers JT, Bare O, Lerin C, Kim SH, Mostoslavsky R, Alt FW, Wu Z \& Puigserver P 2007 Metabolic control of muscle mitochondrial function and fatty acid oxidation through SIRT1/PGC1a. EMBO Journal 26 1913-1923. (doi:10.1038/sj.emboj.7601633)

Grandison RC, Piper MD \& Partridge L 2009 Amino-acid imbalance explains extension of lifespan by dietary restriction in Drosophila. Nature 462 1061-1064. (doi:10.1038/nature08619)

Guarente L 2006 Sirtuins as potential targets for metabolic syndrome. Nature 444 868-874. (doi:10.1038/nature05486)

Guarente L \& Kenyon C 2000 Genetic pathways that regulate ageing in model organisms. Nature 408 255-262. (doi:10.1038/35041700)

Harrison DE, Strong R, Sharp ZD, Nelson JF, Astle CM, Flurkey K, Nadon NL, Wilkinson JE, Frenkel K, Carter CS et al. 2009 Rapamycin fed late in life extends lifespan in genetically heterogeneous mice. Nature 460 392-395. (doi:10.1038/nature08221)
Heilbronn LK \& Ravussin E 2003 Calorie restriction and aging: review of the literature and implications for studies in humans. American Journal of Clinical Nutrition 78 361-369.

Heilbronn LK, de Jonge L, Frisard MI, DeLany JP, Larson-Meyer DE, Rood J, Nguyen T, Martin CK, Volaufova J, Most MM et al. 2006 Effect of 6-month calorie restriction on biomarkers of longevity, metabolic adaptation, and oxidative stress in overweight individuals: a randomized controlled trial. Journal of the American Medical Association 295 1539-1548. (doi:10.1001/jama.295.13.1539)

Hine C, Harputlugil E, Zhang Y, Ruckenstuhl C, Lee BC, Brace L, Longchamp A, Trevino-Villarreal JH, Mejia P, Ozaki CK et al. 2015 Endogenous hydrogen sulfide production is essential for dietary restriction benefits. Cell 160 132-144. (doi:10.1016/j.cell.2014.11.048)

Hosono R, Nishimoto S \& Kuno S 1989 Alterations of life span in the nematode Caenorhabditis elegans under monoxenic culture conditions. Experimental Gerontology 24 251-264.

Houthoofd K, Braeckman BP, Lenaerts I, Brys K, De Vreese A, Van Eygen S \& Vanfleteren JR 2002 Axenic growth up-regulates mass-specific metabolic rate, stress resistance, and extends life span in Caenorhabditis elegans. Experimental Gerontology 37 1371-1378. (doi:10.1016/S05315565(02)00173-0)

Howitz KT, Bitterman KJ, Cohen HY, Lamming DW, Lavu S, Wood JG, Zipkin RE, Chung P, Kisielewski A, Zhang LL et al. 2003 Small molecule activators of sirtuins extend Saccharomyces cerevisiae lifespan. Nature 425 191-196. (doi:10.1038/nature01960)

Hsieh CC, DeFord JH, Flurkey K, Harrison DE \& Papaconstantinou J 2002 Effects of the Pit1 mutation on the insulin signaling pathway: implications on the longevity of the long-lived Snell dwarf mouse. Mechanisms of Ageing and Development 123 1245-1255. (doi:10.1016/ S0047-6374(02)00037-4)

Hubbard BP \& Sinclair DA 2014 Small molecule SIRT1 activators for the treatment of aging and age-related diseases. Trends in Pharmacological Sciences 35 146-154. (doi:10.1016/j.tips.2013.12.004)

Ingram DK \& Roth GS 2015 Calorie restriction mimetics: can you have your cake and eat it, too? Ageing Research Reviews 20C 46-62. (doi:10.1016/ j.arr.2014.11.005)

Ingram DK, Culter RG, Weindruch R, Renquist DM, Knapka JJ, April M, Belcher CT, Clark MA, Hatcherson CD, Marriott BM et al. 1990 Dietary restriction and aging: the initiation of a primate study. Journals of Gerontology. Series A, Biological Sciences and Medical Sciences $\mathbf{4 5}$ B148-B163. (doi:10.1093/geronj/45.5.B148)

Ingram DK, Anson RM, de Cabo R, Mamczarz J, Zhu M, Mattison J, Lane MA \& Roth GS 2004 Development of calorie restriction mimetics as a prolongevity strategy. Annals of the New York Academy of Sciences 1019 412-423. (doi:10.1196/annals.1297.074)

Jacinto E, Loewith R, Schmidt A, Lin S, Ruegg MA, Hall A \& Hall MN 2004 Mammalian TOR complex 2 controls the actin cytoskeleton and is rapamycin insensitive. Nature Cell Biology 6 1122-1128. (doi:10.1038/ ncb1183)

Jensen K, McClure C, Priest NK \& Hunt J 2015 Sex-specific effects of protein and carbohydrate intake on reproduction but not lifespan in Drosophila melanogaster. Aging Cell [in press]. (doi:10.1111/acel.12333)

Kaeberlein M, Powers RW III, Steffen KK, Westman EA, Hu D, Dang N, Kerr EO, Kirkland KT, Fields S \& Kennedy BK 2005 Regulation of yeast replicative life span by TOR and Sch9 in response to nutrients. Science 310 1193-1196. (doi:10.1126/science.1115535)

Kapahi P, Chen D, Rogers AN, Katewa SD, Li PW, Thomas EL \& Kockel L 2010 With TOR, less is more: a key role for the conserved nutrient-sensing TOR pathway in aging. Cell Metabolism 11 453-465. (doi:10.1016/j.cmet.2010.05.001)

Kenyon C, Chang J, Gensch E, Rudner A \& Tabtiang R 1993 A C. elegans mutant that lives twice as long as wild type. Nature 366 461-464. (doi:10.1038/366461a0)

Laeger T, Henagan TM, Albarado DC, Redman LM, Bray GA, Noland RC, Munzberg H, Hutson SM, Gettys TW, Schwartz MW et al. 2014 FGF21 is

Published by Bioscientifica Ltd. 
an endocrine signal of protein restriction. Journal of Clinical Investigation 124 3913-3922. (doi:10.1172/JCI74915)

Le Couteur DG, McLachlan AJ, Quinn RJ, Simpson SJ \& de Cabo R 2012 Aging biology and novel targets for drug discovery. Journals of Gerontology. Series A, Biological Sciences and Medical Sciences 67 168-174. (doi:10.1093/gerona/glr095)

Le Couteur DG, Tay SS, Solon-Biet SM, Bertolino P, McMahon AC, Cogger VC, Pichaud N, Horan M, Correa C, Melvin RG et al. 2014 The influence of macronutrients on splanchnic and hepatic lymphocytes in aging mice. Journals of Gerontology. Series A, Biological Sciences and Medical Sciences [in press]. (doi:10.1093/gerona/glu196)

Lee KP, Simpson SJ, Clissold FJ, Brooks R, Ballard JW, Taylor PW, Soran N \& Raubenheimer D 2008 Lifespan and reproduction in Drosophila: new insights from nutritional geometry. PNAS 105 2498-2503. (doi:10.1073/pnas.0710787105)

Lees EK, Krol E, Grant L, Shearer K, Wyse C, Moncur E, Bykowska AS, Mody N, Gettys TW \& Delibegovic M 2014 Methionine restriction restores a younger metabolic phenotype in adult mice with alterations in fibroblast growth factor 21. Aging Cell 13 817-827. (doi:10.1111/acel. 12238)

Levine ME, Suarez JA, Brandhorst S, Balasubramanian P, Cheng CW, Madia F, Fontana L, Mirisola MG, Guevara-Aguirre J, Wan J et al. 2014 Low protein intake is associated with a major reduction in IGF-1, cancer, and overall mortality in the 65 and younger but not older population. Cell Metabolism 19 407-417. (doi:10.1016/j.cmet.2014. 02.006)

Liao CY, Rikke BA, Johnson TE, Diaz V \& Nelson JF 2010 Genetic variation in the murine lifespan response to dietary restriction: from life extension to life shortening. Aging Cell 9 92-95. (doi:10.1111/j.14749726.2009.00533.x)

Lin SJ, Defossez PA \& Guarente L 2000 Requirement of NAD and SIR2 for life-span extension by calorie restriction in Saccharomyces cerevisiae. Science 289 2126-2128. (doi:10.1126/science.289.5487.2126)

Lin S-J, Ford E, Haigis M, Liszt G \& Guarente L 2004 Calorie restriction extends yeast life span by lowering the level of NADH. Genes \& Development 18 12-16. (doi:10.1101/gad.1164804)

Longo VD \& Kennedy BK 2006 Sirtuins in aging and age-related disease. Cell 126 257-268. (doi:10.1016/j.cell.2006.07.002)

Mair W, Piper MD \& Partridge L 2005 Calories do not explain extension of life span by dietary restriction in Drosophila. PLoS Biology 3 e223. (doi:10.1371/journal.pbio.0030223)

Mair W, Morantte I, Rodrigues AP, Manning G, Montminy M, Shaw RJ \& Dillin A 2011 Lifespan extension induced by AMPK and calcineurin is mediated by CRTC-1 and CREB. Nature 470 404-408. (doi:10.1038/ nature09706)

Maklakov AA, Simpson SJ, Zajitschek F, Hall MD, Dessmann J, Clissold F, Raubenheimer D, Bonduriansky R \& Brooks RC 2008 Sex-specific fitness effects of nutrient intake on reproduction and lifespan. Current Biology 18 1062-1066. (doi:10.1016/j.cub.2008.06.059)

Martin-Montalvo A, Mercken EM, Mitchell SJ, Palacios HH, Mote PL, Scheibye-Knudsen M, Gomes AP, Ward TM, Minor RK, Blouin MJ et al. 2013 Metformin improves healthspan and lifespan in mice. Nature Communications 4 2192. (doi:10.1038/ncomms3192)

Masoro EJ 1991 Use of rodents as models for the study of "normal aging": conceptual and practical issues. Neurobiology of Aging 12 639-643. (doi:10.1016/0197-4580(91)90114-Y)

Masoro EJ 2000 Caloric restriction and aging: an update. Experimental Gerontology 35 299-305. (doi:10.1016/S0531-5565(00)00084-X)

Masoro EJ 2003 Subfield history: caloric restriction, slowing aging, and extending life. Science of Aging Knowledge Environment 2003 RE2. (doi:10.1126/sageke.2003.8.re2)

Masoro EJ 2005 Overview of caloric restriction and ageing. Mechanisms of Ageing and Development 126 913-922. (doi:10.1016/j.mad.2005. 03.012)
Masoro EJ, Yu BP \& Bertrand HA 1982 Action of food restriction in delaying the aging process. PNAS 79 4239-4241. (doi:10.1073/pnas.79. 13.4239)

Mattison JA, Lane MA, Roth GS \& Ingram DK 2003 Calorie restriction in rhesus monkeys. Experimental Gerontology 38 35-46. (doi:10.1016/ S0531-5565(02)00146-8)

Mattison JA, Roth GS, Beasley TM, Tilmont EM, Handy AM, Herbert RL, Longo DL, Allison DB, Young JE, Bryant M et al. 2012 Impact of caloric restriction on health and survival in rhesus monkeys from the NIA study. Nature 489 318-321. (doi:10.1038/nature11432)

Mattson MP, Allison DB, Fontana L, Harvie M, Longo VD, Malaisse WJ, Mosley M, Notterpek L, Ravussin E, Scheer FAJL et al. 2014 Meal frequency and timing in health and disease. PNAS 111 16647-16653. (doi:10.1073/pnas.1413965111)

McCarty MF 2004 Chronic activation of AMP-activated kinase as a strategy for slowing aging. Medical Hypotheses 63 334-339. (doi:10.1016/j.mehy. 2004.01.043)

McCay CM, Dilley WE \& Crowell MF 1929 Growth rates of brook trout reared upon purified rations, upon dry skim milk diets, and upon feed combinations of cereal grains. Journal of Nutrition $\mathbf{1}$ 233-246.

McCay CM, Crowell MF \& Maynard LA 1935 The effect of retarded growth upon the length of life span and upon the ultimate body size. Journal of Nutrition 10 63-79.

Mercken EM, Carboneau BA, Krzysik-Walker SM \& de Cabo R 2012 Of mice and men: the benefits of caloric restriction, exercise, and mimetics. Ageing Research Reviews 11 390-398. (doi:10.1016/j.arr.2011. 11.005)

Mercken EM, Hu J, Krzysik-Walker S, Wei M, Li Y, McBurney MW, de Cabo R \& Longo VD 2013 SIRT1 but not its increased expression is essential for lifespan extension in caloric restricted mice. Aging Cell $\mathbf{1 3}$ 193-196. (doi:10.1111/acel.12151)

Mercken EM, Mitchell SJ, Martin-Montalvo A, Minor RK, Almeida M, Gomes AP, Scheibye-Knudsen M, Palacios HH, Licata JJ, Zhang YQ et al. 2014 SRT2104 extends survival of male mice on a standard diet and preserves bone and muscle mass. Aging Cell 13 787-796. (doi:10.1111/ acel.12220)

Miller RA, Buehner G, Chang Y, Harper JM, Sigler R \& Smith-Wheelock M 2005 Methionine-deficient diet extends mouse lifespan, slows immune and lens aging, alters glucose, $\mathrm{T}_{4}$, IGF-I and insulin levels, and increases hepatocyte MIF levels and stress resistance. Aging Cell 4 119-125. (doi:10.1111/j.1474-9726.2005.00152.x)

Miller RA, Harrison DE, Astle CM, Baur JA, Boyd AR, de Cabo R, Fernandez E, Flurkey K, Javors MA, Nelson JF et al. 2011 Rapamycin, but not resveratrol or simvastatin, extends life span of genetically heterogeneous mice. Journals of Gerontology. Series A, Biological Sciences and Medical Sciences 66 191-201. (doi:10.1093/ gerona/glq178)

Milman S, Atzmon G, Huffman DM, Wan J, Crandall JP, Cohen P \& Barzilai N 2014 Low insulin-like growth factor-1 level predicts survival in humans with exceptional longevity. Aging Cell 13 769-771. (doi:10.1111/acel.12213)

Milne JC, Lambert PD, Schenk S, Carney DP, Smith JJ, Gagne DJ, Jin L, Boss O, Perni RB, Vu CB et al. 2007 Small molecule activators of SIRT1 as therapeutics for the treatment of type 2 diabetes. Nature $\mathbf{4 5 0}$ 712-716. (doi:10.1038/nature06261)

Minor RK, Allard JS, Younts CM, Ward TM \& de Cabo R 2010 Dietary interventions to extend life span and health span based on calorie restriction. Journals of Gerontology. Series A, Biological Sciences and Medical Sciences 65A 695-703. (doi:10.1093/gerona/glq042)

Mitchell SJ, Martin-Montalvo A, Mercken EM, Palacios HH, Ward TM, Abulwerdi G, Minor RK, Vlasuk GP, Ellis JL, Sinclair DA et al. 2014 The SIRT1 activator SRT1720 extends lifespan and improves health of mice fed a standard diet. Cell Reports 6 836-843. (doi:10.1016/j.celrep.2014. 01.031)

Published by Bioscientifica Ltd. 
Nakagawa S, Lagisz M, Hector KL \& Spencer HG 2012 Comparative and meta-analytic insights into life-extension via dietary restriction. Aging Cell 11 401-409. (doi:10.1111/j.1474-9726.2012.00798.x)

Newgard CB 2012 Interplay between lipids and branched-chain amino acids in development of insulin resistance. Cell Metabolism 15 606-614. (doi:10.1016/j.cmet.2012.01.024)

Nisoli E, Tonello C, Cardile A, Cozzi V, Bracale R, Tedesco L, Falcone S, Valerio A, Cantoni O, Clementi E et al. 2005 Calorie restriction promotes mitochondrial biogenesis by inducing the expression of eNOS. Science 310 314-317. (doi:10.1126/science.1117728)

Orentreich N, Matias JR, DeFelice A \& Zimmerman JA 1993 Low methionine ingestion by rats extends life span. Journal of Nutrition 123 269-274.

Pamplona R \& Barja G 2006 Mitochondrial oxidative stress, aging and caloric restriction: the protein and methionine connection. Biochimica et Biophysica Acta 1757 496-508. (doi:10.1016/j.bbabio. 2006.01.009)

Paoli P, Wakeling L, Wright G \& Ford D 2014 The dietary proportion of essential amino acids and Sir2 influence lifespan in the honeybee. Age 36 1239-1247. (doi:10.1007/s11357-014-9649-9)

Partridge L 2014 Intervening in ageing to prevent the diseases of ageing. Trends in Endocrinology and Metabolism 25 555-557. (doi:10.1016/j.tem. 2014.08.003)

Partridge L, Piper MD \& Mair W 2005 Dietary restriction in Drosophila. Mechanisms of Ageing and Development 126 938-950. (doi:10.1016/j. mad.2005.03.023)

Pearson KJ, Baur JA, Lewis KN, Peshkin L, Price NL, Labinskyy N, Swindell WR, Kamara D, Minor RK, Perez E et al. 2008 Resveratrol delays age-related deterioration and mimics transcriptional aspects of dietary restriction without extending life span. Cell Metabolism $\mathbf{8}$ 157-168. (doi:10.1016/j.cmet.2008.06.011)

Piper MD, Mair W \& Partridge L 2005 Counting the calories: the role of specific nutrients in extension of life span by food restriction. Journals of Gerontology. Series A, Biological Sciences and Medical Sciences 60 549-555. (doi:10.1093/gerona/60.5.549)

Piper MD, Partridge L, Raubenheimer D \& Simpson SJ 2011 Dietary restriction and aging: a unifying perspective. Cell Metabolism 14 154-160. (doi:10.1016/j.cmet.2011.06.013)

Powers RW III, Kaeberlein M, Caldwell SD, Kennedy BK \& Fields S 2006 Extension of chronological life span in yeast by decreased TOR pathway signaling. Genes and Development 20 174-184. (doi:10.1101/gad. 1381406)

Ramsey JJ, Colman RJ, Binkley NC, Christensen JD, Gresel TA, Kemnitz JW \& Weindruch R 2000 Dietary restriction and aging in rhesus monkeys: the University of Wisconsin study. Experimental Gerontology 35 1131-1149. (doi:10.1016/S0531-5565(00)00166-2)

Richie J Jr, Leutzinger Y, Parthasarathy S, Malloy V, Orentreich N \& Zimmerman J 1994 Methionine restriction increases blood glutathione and longevity in F344 rats. FASEB Journal 8 1302-1307.

Robertson LT, Trevino-Villarreal JH, Mejia P, Grondin Y, Harputlugil E, Hine C, Vargas D, Zheng H, Ozaki CK, Kristal BS et al. 2015 Protein and calorie restriction contribute additively to protection from renal ischemia reperfusion injury partly via leptin reduction in male mice. Journal of Nutrition [in press].

Rodgers JT, Lerin C, Haas W, Gygi SP, Spiegelman BM \& Puigserver P 2005 Nutrient control of glucose homeostasis through a complex of PGC- $1 \alpha$ and SIRT1. Nature 434 113-118. (doi:10.1038/nature03354)

Shinmura K, Tamaki K, Saito K, Nakano Y, Tobe T \& Bolli R 2007 Cardioprotective effects of short-term caloric restriction are mediated by adiponectin via activation of AMP-activated protein kinase. Circulation 116 2809-2817. (doi:10.1161/CIRCULATIONAHA.107. 725697)

Simpson SJ \& Raubenheimer D 2007 Caloric restriction and aging revisited: the need for a geometric analysis of the nutritional bases of aging. Journals of Gerontology. Series A, Biological Sciences and Medical Sciences 62 707-713. (doi:10.1093/gerona/62.7.707)
Simpson SJ \& Raubenheimer D 2009 Macronutrient balance and lifespan. Aging 1 875-880.

Simpson SJ \& Raubenheimer D 2012 The Nature of Nutrition. A Unifying Framework Form Animal Adaption to Human Obesity. Princeton: Princeton University Press.

Simpson SJ, Le Couteur DG \& Raubenheimer D 2015 Putting the balance back in diet. Cell Metabolism 161 18-23. (doi:10.1016/j.cell. 2015.02.033)

Sinclair DA 2005 Toward a unified theory of caloric restriction and longevity regulation. Mechanisms of Ageing and Development 126 987-1002. (doi:10.1016/j.mad.2005.03.019)

Sinclair DA \& Guarente L 2014 Small-molecule allosteric activators of sirtuins. Annual Review of Pharmacology and Toxicology 54 363-380. (doi:10.1146/annurev-pharmtox-010611-134657)

Skorupa DA, Dervisefendic A, Zwiener J \& de Pletcher SD 2008 Dietary composition specifies consumption, obesity, and lifespan in Drosophila melanogaster. Aging Cell 7 478-490. (doi:10.1111/j.1474-9726. 2008.00400.x)

Solon-Biet SM, McMahon AC, Ballard J, William O, Ruohonen K, Wu LE, Cogger VC, Warren A, Huang X, Pichaud N et al. 2014 The ratio of macronutrients, not caloric intake, dictates cardiometabolic health, aging, and longevity in ad libitum-fed mice. Cell Metabolism 19 418-430. (doi:10.1016/j.cmet.2014.02.009)

Solon-Biet SM, Walters KA, Simanainen UK, McMahon AC, Ruohonen K, Ballard JWO, Raubenheimer D, Handelsman DJ, Le Couteur DG \& Simpson SJ $2015 a$ Macronutrient balance, reproductive function, and lifespan in aging mice. PNAS 112 3481-3486. (doi:10.1073/pnas. 1422041112)

Solon-Biet SM, Mitchell SJ, Coogan SC, Cogger VC, Gokarn R, McMahon AC, Raubenheimer D, de Cabo R, Simpson SJ \& Le Couteur DG $2015 b$ Dietary protein to carbohydrate ratio and caloric restriction: comparing metabolic outcomes in mice. Cell Reports.

Speakman JR \& Mitchell SE 2011 Caloric restriction. Molecular Aspects of Medicine 32 159-221. (doi:10.1016/j.mam.2011.07.001)

Stanfel MN, Shamieh LS, Kaeberlein M \& Kennedy BK 2009 The TOR pathway comes of age. Biochimica et Biophysica Acta 1790 1067-1074. (doi:10.1016/j.bbagen.2009.06.007)

Stone KP, Wanders D, Orgeron M, Cortez CC \& Gettys TW 2014 Mechanisms of increased in vivo insulin sensitivity by dietary methionine restriction in mice. Diabetes 63 3721-3733. (doi:10.2337/ db14-0464)

Sun C, Zhang F, Ge X, Yan T, Chen X, Shi X \& Zhai Q 2007 SIRT1 improves insulin sensitivity under insulin-resistant conditions by repressing PTP1B. Cell Metabolism 6 307-319. (doi:10.1016/j.cmet. 2007.08.014)

Sun L, Sadighi Akha AA, Miller RA \& Harper JM 2009 Life-span extension in mice by preweaning food restriction and by methionine restriction in middle age. Journals of Gerontology. Series A, Biological Sciences and Medical Sciences 64A 711-722. (doi:10.1093/ gerona/glp051)

Taormina G \& Mirisola MG 2014 Calorie restriction in mammals and simple model organisms. BioMed Research International 2014308690. (doi:10.1155/2014/308690)

Tatar M, Post S \& Yu K 2014 Nutrient control of Drosophila longevity. Trends in Endocrinology and Metabolism 25 509-517. (doi:10.1016/j.tem.2014. 02.006)

Tato I, Bartrons R, Ventura F \& Rosa JL 2011 Amino acids activate mammalian target of rapamycin complex 2 (mTORC2) via PI3K/Akt signaling. Journal of Biological Chemistry 286 6128-6142. (doi:10.1074/ jbc.M110.166991)

Valerio A, D’Antona G \& Nisoli E 2011 Branched-chain amino acids, mitochondrial biogenesis, and healthspan: an evolutionary perspective. Aging 3 464-478.

Walford RL, Harris SB \& Gunion MW 1992 The calorically restricted low-fat nutrient-dense diet in Biosphere 2 significantly lowers blood glucose,

Published by Bioscientifica Ltd. 
total leukocyte count, cholesterol, and blood pressure in humans. PNAS 89 11533-11537. (doi:10.1073/pnas.89.23.11533)

Wang X \& Proud CG 2009 Nutrient control of TORC1, a cell-cycle regulator. Trends in Cell Biology 19 260-267. (doi:10.1016/j. tcb.2009.03.005)

Weindruch R, Walford RL, Fligiel S \& Guthrie D 1986 The retardation of aging in mice by dietary restriction: longevity, cancer, immunity and lifetime energy intake. Journal of Nutrition 116 641-654.

Wilder SM, Le Couteur DG \& Simpson SJ 2012 Diet mediates the relationship between longevity and reproduction in mammals. Age $\mathbf{3 5}$ 921-927. (doi:10.1007/s11357-011-9380-8)

Wolf NS, Penn PE, Jiang D, Fei RG \& Pendergrass WR 1995 Caloric restriction: conservation of in vivo cellular replicative capacity accompanies life-span extension in mice. Experimental Cell Research $\mathbf{2 1 7}$ 317-323. (doi:10.1006/excr.1995.1092)
Wu Z, Liu SQ \& Huang D 2013 Dietary Restriction Depends on Nutrient Composition to Extend Chronological Lifespan in Budding Yeast Saccharomyces cerevisiae. PLoS One 8 e64448. (doi:10.1371/journal. pone.0064448)

Yuan R, Tsaih SW, Petkova SB, De Evsikova CM, Xing S, Marion MA, Bogue MA, Mills KD, Peters LL, Bult CJ et al. 2009 Aging in inbred strains of mice: study design and interim report on median lifespans and circulating IGF1 levels. Aging Cell 8 277-287. (doi:10.1111/j.14749726.2009.00478.x)

Yuan HX, Xiong Y \& Guan KL 2013 Nutrient sensing, metabolism, and cell growth control. Molecular Cell 49 379-387. (doi:10.1016/j.molcel.2013. 01.019)

Zimmerman JA, Malloy V, Krajcik R \& Orentreich N 2003 Nutritional control of aging. Experimental Gerontology 38 47-52. (doi:10.1016/ S0531-5565(02)00149-3)

Received in final form 21 May 2015

Accepted 28 May 2015

Accepted Preprint published online 28 May 2015
(C) 2015 Society for Endocrinology Printed in Great Britain
Published by Bioscientifica Ltd. 